\title{
Self, Eternity, and the Mysteries: A Speculative Response to Kenneth Ring's Paper
}

\author{
Michael Grosso \\ Department of Philosophy \\ Jersey City State College
}

\begin{abstract}
This response to a paper by Kenneth Ring (1984) deals with three issues of broad philosophical import: (1) near-death experiences (NDEs) and the expanded sense of self-identity; (2) the distinction between postmortem survival and the experience of premortem eternity; and (3) the relation between NDEs and the idea of mystery cults, ancient and modern. Four properties in particular are singled out to identify the expanded NDE-mediated Self: a new attitude toward the body; the emergence of the observing mind; extended psychic sensitivity; and the potential for transpersonal love. These features of the NDE are viewed in light of a model of a more evolved human being, marked especially by a pacific disposition. Near-death research offers fresh empirical data for individuals to revise their personal mythology of life and death.
\end{abstract}

\section{INTRODUCTION}

In a recent paper Kenneth Ring (1984) reminded us of the neglected writings of Paul Brunton, an articulate explorer of the human psyche. But we are indebted to Ring for something else, no less important; Ring never hesitates to take hold of what is vital in the study of the near-death experience (NDE) and to raise questions that touch our deepest concerns. One of the oddities of recent intellectual life is that the majority of academic philosophers no longer grapple with the old questions. There are exceptions, of course, but more often it is the physicists, the biologists, and the psychologists who speculate on the ancient questions, such as Who are we? Where did we come from? and Where are we going? The quest associated with traditional metaphysics, of forging a synoptic world-view, is no longer considered the province of philosophy. Our academic philosophers spend their time honing the weapons of analysis, but too

Anabiosis - The Joumal for Near-Death

Studies, Fall 1984, Vol. 4, No. 2 
often use them to attack butterflies and gnats.

Ring's paper raises a number of "big" questions and I wish briefly to comment on three of them. The first deals with the nature of self or personal identity and the NDE. The second has to do with the important distinction between postmortem survival and the premortem experience of eternity. The third concerns NDEs and the mystery cults of antiquity. Needless to say, all the problems and challenges of empirical research remain; however, there is value in keeping up the dialogue on the larger, philosophical questions raised by the study of the NDE.

\section{NDES AND THE AUTHENTIC SELF}

Modern philosophers, from David Hume on, have occupied themselves with determining criteria for identifying a person. What entitles me to say that I am the same person I presumably was ten years ago? Is it my body? My memories? Is it something only I have direct access to, or is it something I must postulate to make sense of the supposed unity of my self? Does my identity consist in something ascribed to me by other people, something publicly observable? Or perhaps my identity is revealed only in an intimate I-thou relationship. The problem is to sift the marks that help us pick out one person from another and that help to determine what makes any person qualify as a person.

These are important philosophical questions, on which hang large issues, such as the logical possibility of postmortem survival. For instance, anyone who decided in advance that the notion of disembodied existence was inherently absurd would probably dismiss out of hand any evidence suggesting postmortem survival. The concept of self or personal identity may have social and political implications as well. The Cartesian doctrine of the "ghost in the machine" has been a favorite whipping boy of contemporary writers, yet as Noam Chomsky (1975) has argued, the Cartesian concept of self is the basis of a tradition of "opposition to tyranny, oppression, and established authority" (p. 132). The later empiricist (Humean) concept of the person, in which an essential core of selfhood is denied, lends itself to a dangerous situation. Writes Chomsky: "If people are, in fact, malleable and plastic beings with no essential psychological nature, then why should they not be controlled and coerced by those who claim authority, special knowledge, and a unique insight into what is best for those less enlightened?" (p. 132). It would be interesting to look more closely into this, and show, 
for instance, how the behaviorist concept of self plays into the hands of Soviet totalitarian repression or Western forms of capitalist exploitation, but the point here is that the philosophical concept of self is not just an academic piffle.

There is also an older tradition of self concepts, rooted in Greek philosophy and Hindu spirituality, that addresses the question of the true, real, or higher self. Here the problem concerns the authenticity question that the empirical NDE bears. The NDE provides psychological experiences that have tremendous significance for one's sense of self. In this near-death gnosticism, special experiences cause a person to identify with a different, larger, authentic self, "authentic" in contrast to "false," "sủperficial," "unreal," etc.

Ring stressed at least four marks of the newly discovered self, "the real me" that emerges from the shadows of pre-NDE existence. In commenting on these marks, I will try to think of them in relation to an image of a new kind of human being. NDEs are interesting in part because they transform people. So we should ask, what will this new race of overselves (Ring, 1984) be like? Brunton's term "overself," by the way, has echoes of Ralph Waldo Emerson's "oversoul," as well as of Friedrich Nietzsche's Ubermensch or overman. Perhaps the NDE can help us to imagine that possible descendent of present humanity. The idea of the evolution of human consciousness has, of course, been around for a long time; the archetypal NDE at least offers a solid empirical model for what that evolved consciousness might be like.

\section{Freedom from the Body}

The-overself, the person who has evolved to the new and higher self, will be detached from the body in the sense that, having seen it "die" and having known the elation of a radical freedom, he or she will cease to feel anxious about its fate. If we identify the ego with the body, and if the seat of anxiety is the ego, then we can liberate the energy invested in that anxiety and turn it to a more erotic experience of the body. For detachment from the body, in short, profound relaxation, is essential for an erotic sense of reality. So in this sense the body is liberated, though not despised or condemned; the old, defeated body is laid aside, but a new spiritual body is discovered, subtler and more plastic, a body of the imagination. Indeed, this new body of light, experienced in many NDEs, has a long spiritual and occult tradition, which can be traced back through Saint Paul to the gnostics and neoplatonists as well as to the sidereal 
mystery cults of Egypt and Babylonia (Mead, 1967).

A person thus detached from the body is apt to be less driven, anxiety ridden, and violent, for as Plato said, the cause of all wars and conflicts, both inner and outer, is, at bottom, bondage to the needs of the body. So this freedom from the body would make for a pacific human being, a quality useful in a world where war can no longer serve anyone's needs. On the other hand, I would not want to see this detachment carried too far, toward fatalistic passivity. We must not let our bodies be used as manure to fertilize the ambitions of the avaricious and the aggressive. Our bodies are also the temples our higher selves inhabit.

\section{The-Observer}

The observing quality of consciousness, the capacity for witnessing and contemplation, is a valuable addition in the model of a new humanity. Pythagoras said that life was like a festival in which some men came to compete in the games, some to sell something, and others, the best, to observe and contemplate. A Marxist might claim this saying merely enshrines an attitude of privilege, the posture of a nonproductive Greek aristocrat. But near-death research suggests the remark hits on a potential of the human mind to become radically detached from all phenomena, all particular forms, all reflex responses. Once again the development of this contemplative and esthetic awareness could have a quieting effect on the human animal; it might help to subdue our overcharged sympathetic nervous systems and create a more relaxed, pleasure-loving, pacific human being: a shaman of peace amid the threat of nuclear destruction.

Here too, though, is the possibility of perversion, if detachment is carried to sterile estheticism. One thinks, for instance, how some people employ the notion of "karma" to cover a certain moral callousness, a cavalier indifference to the injustice and the suffering of others. There is the danger of becoming detached to the point of becoming dehumanized. I mention this not to bore the reader with moralistic patter but to stress that the individuation of the Self is always a unique and concrete process, and that no qualities, even those of the higher Self, are immune from the constraints of context.

The Self and the NDE can also be handled in a Jungian framework, and Ring and I agree that we need to keep looking for better frameworks and conceptual grids to order and interpret the NDE. Brunton and Carl Jung (1959) both stressed the category of the transpersonal, an entity, process, life, form, etc. that is autonomous, logically 
independent from, and over and above the personal mind. But such a notion does not destroy the personal mind; it only gives it a new environment to extend its process of development.

For Jung the ego was a process of becoming aware of a larger process, less restricted by space and time, which he called the Self or the Objective Psyche. All the great, honorific, abstract terms including overself and oversoul and atman and kingdom of God seem to point to possible extensions of experience; their main use is, as William James might have said, to excite the Yes function, to liberate Eros from submission to Thanatos. Once again the value in terms of survival would be to help toward the evolution of a human type that thinks and feels in a universal spirit, that, like Saint Francis, can see brotherhood and sisterhood in the whole of creation. The adaptive value of this in a world split into warring factions, and spellbound by the murderous shibboleths of race, religion, and ideology, would be considerable.

\section{Extended Psychic Sensitivity}

The "real me" that emerges in the NDE also displays extended psychic sensitivity. Of course, one might imagine malign possibilities here, but let us instead try to picture an evolved Self that is pacific. Again, extended psychic sensitivity as a common trait would indeed have a profoundly transformative effect on humanity. Our overself would be, as Jesus in the gnostic gospel of Thomas said, radically honest and open; there could be no secrets because the inner man would inform the outer man. It would be the end of repression, and with it the whole cycle of aggression and guilt, the cycle Sigmund Freud (1961) said in Civilization and Its Discontents is driving us deeper into war and self-destruction.

Extended psychic sensitivity would make it more natural to be sympathetic and empathetic toward other beings, to resonate with the inner worlds of others. Morality would cease to be coercive; logically, we would still feel only our own feelings, and retain a monadic center of autonomy. Cosmic mush would not follow, but neither would cosmic strife and obtuse insensitivity be the routine way of being. We needn't go so far as to invoke the concept of omniscience; all that is necessary is to picture a significant increase of telepathic receptivity. A telepathically mediated morality plus a drastic reduction of repression would be quite enough to engender a revolution in social relationships. 


\section{Supernatural Love}

According to Ring, the deepest NDErs experience the kind of love that forced Dante Alighieri to invent a new word: trasumanar - to transcend humanity (1962, Canto I, line 70). In the depths of the NDE a supernatural love is encountered: a love that transcends the quality of ordinary human love, a love said to be "unconditional," though ordinary human love may have intimations of it in its best moments. Surely any psychologist or philosopher of human potential interested in empirical models for the evolution of consciousness must stop and ponder this. Even the smallest hints should be seized upon here, for what greater discovery could science make than of a source, buried in the transpersonal depths of humanity, of a supernatural, transfiguring love? The idea that such a power is latent within us is staggering.

Some near-death experiencers, at least in the Western world, identify Christ as the luminous, higher consciousness encountered. Christ's declaration that the kingdom of God is within us may indeed be a prophetic statement about the evolution of the possible Self. Again, Jung is a help here, who said that Christ is the symbol of the Self, of the process whereby the ego expands to a whole Self. For Jung (1959, Pp. 36-71) this meant that each individual had to become a Self in an individual way, except that at the center of each individual was the love that in the end would strike harmonious chords out of the most jarring notes and protean dynamics. Teilhard de Chardin (1965) said that evolution is both a complexification and a centralization of life, a reaching out in many directions, a celebration of diversity, but in a way that is a homecoming, a converging at the summit. Such is the Self we might picture as latent in the collective psyche, the Overself as glimpsed perhaps in the deepest transformative NDEs.

\section{SURVIVAL AND ETERNITY}

Ring makes a crucial distinction in his paper. There seem to be two ways to escape the anxiety implicit in being creatures mired in time. One is to continue to move along a horizontal axis. The hope for survival of bodily death is the hope for this horizontal extension of the reflective aspect of the mind; constricted and anxiety ridden, aggressive and exclusive, the ego as an abstraction of the Self craves to survive in the shallows of time.

But another axis of escape exists: the vertical axis of eternity. 
What is eternity? The most intriguing definition I can think of is that of Boethius (1962), the sixth-century Roman philosopher. "Eternity," he said, "is the whole, perfect, and simultaneous possession of infinite life" (p. 115). One quality of this simultaneity is reflected in near-death reports of panoramic memory. Much more is meant, no doubt, doomed to languish in the limbo of the ineffable. One thing we can say: eternity is a quality of the here and now; it is fullness, the wholeness of infinite life found in the finite. It is not some vaporous expansion into clouds of nothingness. It is the soul of transience: ". . . he who kisses the joy as it flies/Lives in eternity's sunrise" (Blake, 1965, p. 461). Eternity is a way of being, a way in which all the moments and feelings and energies of the past, even perhaps of the future, are present and compressed in a form that is completely alive with the duration of our lives. The formulas of philosophers and scientists can at best point fingers toward William Blake's sunrise. Even the poets, mystics, and deep NDErs can only trace shadows of the brilliance. Eternity is possession of our whole selves, all our parts and memories revived, hopes fulfilled, angers transfused by love, loves clarified in spirit. In that way of being, the tiniest leaf or grain of sand lights up, a wonder, as Blake and Thomas Traherne (1960) and the Zen painters showed; the peace of God is here incompatible with the fear of death. Perfect love casteth out fear. The question of survival, otherwise so urgent, the anxious need to persist as an isolated, reflective part of consciousness, fades away.

Once again this quality of consciousness, in which the fullness of being becomes holographically concentrated in every atom, in which a heaven may be seen in a wildflower, adds to our image of a new and pacific humanity. Eternity as the whole and perfect presence of what is present frees us from regret over the past, from grasping for the future. It destroys the rationale of Type A personalities, those addicts of linear time. The near-death experience offers a new concept and experience of time, an expansion of time-sense evidenced both in flashbacks and prophetic visions, and in that vertical descent into the presence of the concrete world, into the unutterable rosebush in the green garden of reality.

\section{THE MYSTERIES : OLD AND NEW}

The time in the ancient world when the Mysteries and their rituals thrived was a time like ours, a period, in Gilbert Murray's (1951) phrase, of "a failure of nerve." The Roman Empire had lost 
its vitality, the old gods had ceased to evoke the vital force in the average denizen of the Empire; the mystery cults flourished as experiential inroads to the wellsprings of the deep psyche. The Mysteries seem like ritual enactments of the near-death experience, and if we are to judge by the testimony of the ancients, the winds of the eternal blew on the brows of many a celebrant. The styles varied, the symbols were diverse, from the wild Dionysian revels, which produced ecstasy amid flute call and drum beat, to the Taurobolian, in which the celebrant soaked himself in the sacred blood of bulls, to Eleusis, in which the mystes entered the telesterion loaded on acid to see an apparition of Persephone, the consort of the god of the underworld. When things worked, one came out renewed, transformed, high on the gods, high on the images of eternity. There were many competing forms of this life-enhancing experience, many paths of experimental near-death.

One of the surprises is that none of them survived; Christianity won out in the competition. Christ became the archetype of the Self in the Western world, the road to the death-healing experience, the symbol that crystallized the collective life force. The old gods were routed by the help of the new church and its propagandists and beaten into the dust of oblivion, into the unconscious of the Western mind.

But now, as we all know, science, a new divinity, has shattered the power of the old healing archetypes. The Christian symbol of the Self is in ruins, reduced to a fundamentalist counterfeit, laden with guilt, an instrument of manipulation; or to a liberal abstraction, a demythologized entity of dubious status; or simply to a de facto joke in the eyes of the secular mob of consumer society.

One place the ancient archetype of the Western overself returns with all the force of the repressed is the hospital deathbed. Amid the scene of ritual resuscitation where, unfortunately, there are no hierophants, no guides, no one to help tease nut the meaning of the experience from the afterglow of the memory, there the mythology of death and enlightenment comes to life, powerful as old, flashing with transforming light, the heights and the abysses all intact. But probably for the great majority, and it would seem we are talking of millions now, one has to say with T. S. Eliot: "we had the experience but missed the meaning" (1952, p. 133). Near-death researchers are helping to resuscitate the meaning and to decipher the Rosetta Stone of the psyche's ancient mysteries.

Still, there is no reason to cheer too loudly. Meaning is always born in an individual creative act, a deed as solitary as dying. In the 
present age each of us must create his own myth. The likelihood is small of reaching a consensus on NDEs, on psi, on anything of weighty bearing about who we are, where we came from, and where we are heading, whether it be toward the omega point of human evolution or toward a global graveyard in a nuclear winter. But at least near-death researchers can go on sharing their findings, setting them out as raw material, as a resource for anyone interested in silf-exploration, who wants to build his own myth of death. Every person's life is a mystery ritual, and it may be the mark of the new age to come that every person will have to be his or her own hierophant.

\section{REFERENCES}

Blake, W. Eternity. In (D.H. Erdman, Ed.), The Poetry and Prose of William Blake. Garden City, NY: Doubleday, 1965.

Boethius. The Consolation of Philosophy. New York: Library of Liberal Arts, 1962.

Chomsky, N. Reflections on Language. New York: Random House, 1975.

Dante Alighieri. Paradiso (P. Wicksteed, Trans.). London: Dent, 1962.

de Chardin, Teilhard. The Phenomenon of Man. New York: Harper Torchbooks, 1965.

Eliot, T. S. The Dry Salvages. In "The Four Quartets" (pp. 117. 149), in The Complete Poems and Plays. New York: Harcourt, Brace, 1952.

Freud, S. Civilization and Its Discontents. New York: Norton, 1961. Jung, C. G. Aion. Princeton, NJ: Princeton University Press, 1959. Mead, G. R. S. The Doctrine of the Subtle Body. Wheaton, IL: Quest, 1967.

Murray, G. The Five Stages of Greek Religion. New York: Doubleday, 1951.

Ring, K. The nature of personal identity in the near-death experience:

Paul Brunton and the ancient tradition. Anabiosis, 1984, 4, 3-20.

Traherne, T. Centuries. New York: Harper and Row, 1960.

Requests for reprints to:

Michael Grosso

1422 River Road

Edgewater, NJ 07020 
